\title{
Measurement of Background Gamma Radiation Levels at Two Tertiary Institutions in Minna, Nigeria
}

\author{
*OLARINOYE, I.O.; *SHARIFAT, I.; *BABA-KUTIGI, A, N.; *KOLO, M.T.; \\ **ALADENIYI, K.
}

\author{
*Dept. of Physics, Federal University of Technology, Minna, Niger state, Nigeria. \\ **Dept. of Science Lab. Tech., Rufus Giwa Poly., Owo, Ondo state, Nigeria. \\ lekeola2005@yahoo.com;07067533885
}

\begin{abstract}
An in-situ measurement of the background radiation level was carried out at the vicinity of three campuses of two major tertiary institutions in Minna. A portable Geiger-Mueller tube-based environmental radiation dosimeter was used for the measurement. A total of 34 point was surveyed across the three institutions for background environmental radiation. The dose rate range obtained are: at the Niger State College of Education Minna (NCM), the dose rate varies from $0.125 \mu \mathrm{Sv} / \mathrm{hr}$ to $0.171 \mu \mathrm{Sv} / \mathrm{hr}$; at the Federal University of Technology Bosso Campus (FUTB) it wass between $0.152 \mu \mathrm{Sv} / \mathrm{hr}$ and $0.184 \mu \mathrm{Sv} / \mathrm{hr}$; and at the Federal University of Technology GidanKwano campus FUTG it was between $0.137 \mu \mathrm{Sv} / \mathrm{hr}$ and $0.184 \mu \mathrm{Sv} / \mathrm{hr}$. In all the 34 points surveyed the mean dose rate was $0.154 \mu \mathrm{Sv} / \mathrm{hr}$ with a standard deviation of $0.017 \mu \mathrm{Sv} / \mathrm{hr}$. Generally, the dose rate level in each of the institutions surveyed are comparable to one another and could simply be attributed to natural sources. The average annual effective dose obtained from this study is $0.189 \mathrm{mSv} /$ annum which is still less than the recommended limit of $1 \mathrm{mSv} / \mathrm{annum}$ by International Commission on Radiation Protection [ICRP] for non occupational population exposure. @ JASEM
\end{abstract}

Radiation from many sources is omnipresent on the earth surface, consequently man is continuously irradiated. The basic difference between ionizing (nuclear) radiation and other common types of radiation in the environment such as heat is that it possesses sufficient energy to cause ionization. In water of which cell are largely composed, ionization can lead to molecular changes and to the formation of chemical species of a type which are damaging to the chromosome material. Ionizing radiation injury is dependent on a number of factors including: The nature (alpha $(\alpha)$, betta $(\beta)$, and gamma $(\gamma)$ ) and energy of the radiation, the dose, time of exposure, homogeneity of dose and shielding. When the dose and dose rate is within the accepted level, the effect of radiation is small and most time no effect is noticed, although the effect of low level radiation are not yet completely understood (ICRP, 1990). Human body is permanently irradiated from two ionizing radiation sources: External and Internal. External radiation sources can either be natural (cosmic, earth) or artificial (e.g. radiation generators), both of equal risk to man. Inside the body, the K-40 is, by its nature present throughout human life. In the case that anyhow (ingestion, inhalation etc), other radionuclide (such as radon in air) enter inside the body, the body becomes internally contaminated.

The level of the natural radioactivity in the soil and in the surrounding environment as well as the associated external exposure due to the gamma radiation depends primarily on the geological and geographical conditions of the region (UNSCEAR, 2000). The geological and geographical definition of an environment dictate to a good degree the radionuclides contained in the soil and rocks there. Soil contains small quantities of radioactive elements along with their progeny. The main sources of the external gamma-radiation are from the primordial radio nuclides like Uranium-238, Thorium-232 and potassium-40 that are present in the earth since its formation. The amount of background radiation in an environment also depends though to a lesser extent upon man activities and soil uses. Consequently, the soil of barren area should show different amount of radioactivity when compared with that of the cultivated soil.

This paper presents the background radiation level and the gamma absorbed dose rate to the students, staffers and member of the general public within three campuses of the two tertiary institutions in Minna (Niger State College of Education MinnaNCM, Federal University of Technology Bosso Campus-FUTB, and the Federal University of Technology Gidan-Kwano campus- FUTG). The values obtained for background radiation from this work will form part of the baseline data for environmental radiation in Niger state which up till now to the best of our knowledge is not available. The data could also be used (in the future) to access the impact of research (scientific and technological) activities on the radiation level in the institutions.

\section{MATERIALS AND METHODS}

Minna is the capital of Niger - the biggest (in land size) state in Nigeria. The population of Minna has increased tremendously over recent years due to many factors. These factors include its closeness to the capital of Nigeria, relative peace, increase in

\footnotetext{
* Corresponding author: Olarinoye, I.O.
} 
enrolment in educational institutions and consequently the increase in business activities in the town. Although the town does not boast of any manufacturing company which utilizes radioactive materials, the geology of the state suggests that environmental radiation level in the state could be significant. Niger State is covered by two major rock formations; the sedimentary and basement complex rocks. The sedimentary rocks to the south are characterized by sandstones and alluvial deposits, particularly along the Niger valley and in most parts of Borgu, Bida, Agaie, Lapai, Mokwa, Lavun, Gbako and Wushishi Local Government Area. This subarea also contains the extensive flood plains of the River Niger and this has made the state to be one of the largest and most fertile agricultural lands in the country. To the north is the basement complex, characterized by granitic outcrops or inselbergs which can be found in the vast topography of rolling landscape. Such inselbergs dominate the landscape in Rafi, Shiroro, Minna, Mariga and Gurara. (Ajibade, 1976).

An in-situ measurement of the background radiation level was carried out at Niger State College of Education Minna-NCM, Federal University of Technology Bosso Campus-FUTB, and the Federal University of Technology Gidan-Kwano campusFUTG using a portable Geiger-Mueller tube-based environmental radiation dosimeter (Digilert Nuclear Radiation Monitor, S.E International, Inc. U.S.A). The dosimeter is exclusively designed to serve as a low level survey meter. It was calibrated with Cesium-137 gamma source. The instrument is capable of measuring gamma dose rates in the range 0-20 mR/hr. These features make this dosimeter an ideal choice for the measurement of gamma dose rate from environmental radiation and also for geological prospecting for radioactive minerals. The areas chosen for background radiation measurement in the institutions were randomly selected but evenly distributed to cover each school compound. They include areas which record high population flux throughout the day. These include: Yahaya Madaki library (YML), Administrative Block (ADB), Female
Hostel (FH), Staff School (SS), School of Language (SL), Intermediate Staff Quarters (ISQ), Junior Staff Quarters (JSQ), Mosque (MSQ), Business Education and Home economics department (BHD) and Simon Oduoye Computer Centre (SCC) for NCM; Mosque (MSQ), Sport Centre (SC), Staff School (SS), Church $(\mathrm{CCH})$, Remedial Centre (RC), Lecture Theatre (LT), Boys Hostel (BH), Agric Building (AB), General Workshop (GWH), Staff Quarters (SQ), Girls Hostel (GH), Library (LIB) for FUTB; and Church $(\mathrm{CCH})$, Mosque (MSQ), Sport complex (SC), Senior Staff Housing (SSH), Boys Hostel (BH), SET Phase II (SET), School of Science II (SSSE), Junior staff Quarters (JSQ), Nursery School (NS), Library (LIB), Cafeteria (CF), and the multifunctional centre (MFC) for FUTG. The monitor was suspended in air via a retort stand at one meter above the ground level (EML, 1983) at open and undisturbed level ground surface. At each point, the total count for 30 minute was recorded. Five successive readings were taken for each point. The average total count was converted to count per minute (cpm) by dividing it by 30 minute. The mean total count (cpm) and standard deviation is presented in table 1 . The average dose rate $(\mu \mathrm{Sv} / \mathrm{hr})$ for each point was obtained by multiplying the average total count $(\mathrm{cpm})$ by a factor of $10^{-2}$.

\section{RESULT AND DISCUSSION}

A total of 34 point was surveyed across the three major high institutions in Minna (NCM, FUTB, and FUTG) for background environmental radiation. The dose rate obtained at each point is presented in table 1. At NCM, the dose rate varies from $0.125 \mu \mathrm{Sv} / \mathrm{hr}$ at SS and MSQ to $0.171 \mu \mathrm{Sv} / \mathrm{hr}$ at YML fig. 1. For FUTB the minimum dose rate of $0.152 \mu \mathrm{Sv} / \mathrm{hr}$ was obtained at SS while the maximum dose of 0.184 $\mu \mathrm{Sv} / \mathrm{hr}$ was obtained at BH Fig.2. At FUTG the minimum dose rate $(0.137 \mu \mathrm{Sv} / \mathrm{hr})$ was obtained at MSQ while the maximum $(0.184 \mu \mathrm{Sv} / \mathrm{hr})$ was at LIB, Fig.3. In all the 34 points surveyed the mean dose rate was $0.154 \mu \mathrm{Sv} / \mathrm{hr}$ with a standard deviation of $0.017 \mu \mathrm{Sv} / \mathrm{hr}$. 

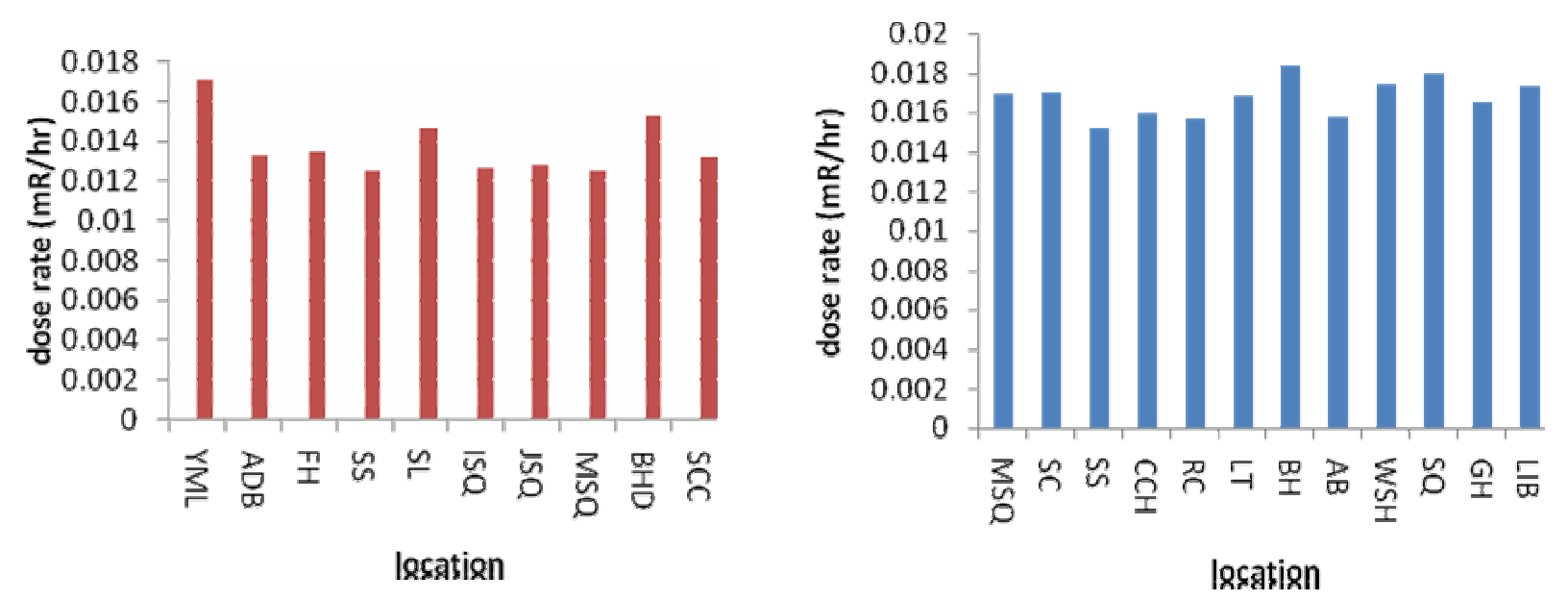

Fig.1. Dose rate for locations at NCM

Fig.2. Dose rate for locations at FUTB.

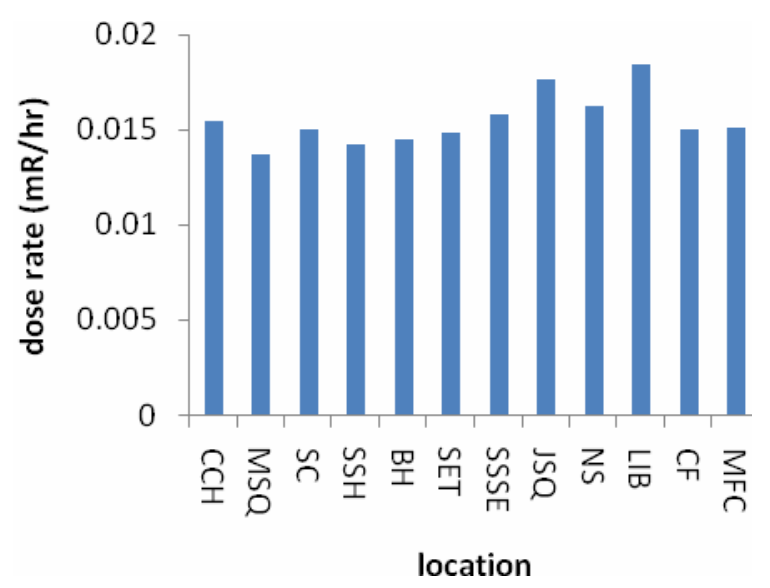

Fig.3. Dose rate for locations at FUTG

Table 1: Comparison of dose rate from this work and other regions

\begin{tabular}{ccc}
\hline Dose rate $(\mathrm{nSv} / \mathrm{hr})$ & Region & Reference \\
\hline 132 & Offa & Nwakwo and Akoshile [2005a] \\
134 & Ilorin & Nwakwo and Akoshile [2005b] \\
253 & Turkey & Merdanoglu and Altinsoy [2006] \\
56.6 & Spain & Beaza et al. [1994] \\
56 & World average & UNSCEAR [1993] \\
117 & Bangalore (India) & Shiva et al. [2008] \\
154 & This work & Olarinoye et al \\
\hline
\end{tabular}

Generally, the dose rate levels in each of the institutions surveyed are comparable to one another and could simply be attributed to natural sources as there are no radiation generators around them. The total mean dose rate of the surveyed areas is found to be roughly thrice that of the world average, and found to be higher than that of other places compared with except Turkey -table 1. Offa and Ilorin are both in Nigeria and about 550 and $500 \mathrm{kM}$ away respectively from the study area, their values are found to be lesser but comparable with that obtained in this work. This may be due to the fact that they have similar geology. The annual effective dose obtained by using the dose conversion factor of $0.7 \mathrm{~Sv} / \mathrm{Gy}$ and assuming the population in the areas surveyed spend $20 \%$ of their day in this area (UNSCEAR, 2000) is still lower than the recommended limit of $1 \mathrm{mSv}$ /annum by International

* Corresponding author: Olarinoye, I.O. 
Commission on Radiation Protection (ICRP, 1990). The average effective annual dose for the 34 point studied is $0.189 \mathrm{mSv} / \mathrm{annum}$ which is still than the ICRP limit value for non occupational population exposure.

Conclusion: The high background radiation observed at the surveyed areas could be attributed only to natural sources (cosmic and terrestrial). The geology of the town suggests that the soil in Minna town has a large deposit of granite. It is well known that granites contain high concentrations of uranium, thorium and potassium (Ivanovich and Harmon, 1982). There is thus a need for a comprehensive radiological study in the areas covered by this work to ascertain the radionuclide responsible for the elevated gamma dose rates. There might be deposit of radioactive mineral around the survey areas. This study has established a external gamma dose rate to the population in Minna. Although dose rate values obtained are higher when compared to values from two other towns in the region and the global average, their effective annual dose is still lesser than the dose limit recommended by the ICRP.

\section{REFERENCES}

Ajibade, AC., (1976): Provisional classification and correlation of the schist belt in Northwestern Nigeria. Elizabethan publishing co, Ibadan, 8587.

Beaza, A, dei Rio M, Miro, C and Paniagua, J. (1994). Natural radionuclide distribution in soils of Caceres (Spain): dosimetry implications. $J$. Environ. Radioactivity, 23 : 19-37.

Environmental Measurement Laboratory (EML). (1983). Procedure manual. New York.

Herman, C. (1996). Introduction to Health Physics 3rd ed. Megrano New York, 233.

ICRP (International Commission on Radiological Protection). Publication 60, (1990).
Recommendations of the International Commission on Radiological Protection, Annals of ICRP vol. 21, No 13 Pergamum Press, Elmsford, NY (1991).

Ivanovich, M and Harmon, RS. (1982). Uranium series disequilibrium in application to environmental problems. Oxford, Clarendon Press, 51-55.

Merdanoglu, B and Altinsoy, N. (2006). Radioactivity concentrations and dose assessment for soil samples from Kestanbol granite area, Turkey. Radiation Protection Dosimetry 121:59-62.

Nwankwo, L I; Akoshile, C O (2005a). Background radiation study of Offa industrial area of Kwara State, Nigeria. J. Appl. Sci. Environ. Manage. 9 (3) $95-98$

Nwankwo, L I; Akoshile, C O (2005b). Monitoring of external background radiation level in Asa Dam Industrial area of Ilorin, Kwara State, Nigeria. J. Appl. Sci. Environ. Manage. 9 (3) 91 $-94$

Shiva, PNG, Nagaiah N, Ashok GV, and Karunakara N. (2008). Concentration of ${ }^{226} \mathrm{Ra},{ }^{232} \mathrm{Th}$, and ${ }^{40} \mathrm{~K}$ in the soils of Bangalore region, India. Health Phys. 94 (3), 264-271.

United Nation Scientific Committee on the Effects of Atomic Radiation (1993) Sources and effect of Ionizing radiation. Report to the general assembly with scientific annaxes. United Nations; New York.

United Nation Scientific Committee on the Effects of Atomic Radiation (2000) Sources and effect of Ionizing radiation. Report to the general assembly with scientific annaxes. United Nations; New York. 